\title{
Diagnosis, treatment and follow-up of Barrett's esophagus: a systematic review
}

\author{
José Roberto ALVES ${ }^{1,3}$, Fabrissio Portelinha GRAFFUNDER ${ }^{2,3}$, João Vitor Ternes RECH ${ }^{2,3}$, \\ Caique Martins Pereira TERNES ${ }^{2,3}$ and lago KOERICH-SILVA ${ }^{2,3}$
}

Received: 27 April 2020 Accepted: 26 June 2020

ABSTRACT - Background - Barrett's esophagus (BE) is a premalignant condition that raises controversy among general practitioners and specialists, especially regarding its diagnosis, treatment, and follow-up protocols. Objective - This systematic review aims to present the particularities and to clarify controversies related to the diagnosis, treatment and surveillance of BE. Methods - A systematic review was conducted on PubMed, Cochrane, and SciELO based on articles published in the last 10 years. PRISMA guidelines were followed and the search was made using MeSH and non-MeSH terms "Barrett" and "diagnosis or treatment or therapy or surveillance". We searched for complete randomized controlled clinical trials or Phase IV studies, carried out with individuals over 18 years old. Results - A total of 42 randomized controlled trials were selected after applying all inclusion and exclusion criteria. A growing trend of alternative and safer techniques to traditional upper gastrointestinal endoscopy were identified, which could improve the detection of BE and patient acceptance. The use of chromoendoscopy-guided biopsy protocols significantly reduced the number of biopsies required to maintain similar BE detection rates. Furthermore, the value of BE chemoprophylaxis with esomeprazole and acetylsalicylic acid was relevant, as well as the establishment of protocols for the follow-up and endoscopic surveillance of patients with BE based predominantly on the presence and degree of dysplasia, as well as on the length of the follow-up affected by BE. Conclusion - Although further studies regarding the diagnosis, treatment and follow-up of BE are warranted, in light of the best evidence presented in the last decade, there is a trend towards electronic chromoendoscopy-guided biopsies for the diagnosis of $\mathrm{BE}$, while treatment should encompass endoscopic techniques such as radiofrequency ablation. Risks of ablative endoscopic methods should be weighted against those of resective surgery. It is also important to consider lifetime endoscopic follow-up for both short and long term BE patients, with consideration to limitations imposed by a range of comorbidities. Unfortunately, there are no randomized controlled trials that have evaluated which is the best recommendation for BE follow-up and endoscopic surveillance ( $>1 \mathrm{~cm}$ ) protocols, however, based on current International Guidelines, it is recommended esophagogastroduodenoscopy (EGD) every 5 years in BE without dysplasia with 1 up to $3 \mathrm{~cm}$ of extension; every 3 years in BE without dysplasia with $>3$ up to $10 \mathrm{~cm}$ of extension, every 6 to 12 months in BE with low grade dysplasia and, finally, EGD every 3 months after ablative endoscopic therapy in cases of BE with high grade dysplasia.

HEADINGS - Barrett esophagus, pathology. Esophagoscopy, methods. Image-guided biopsy, methods. Carcinogenesis. Metaplasia.

\section{INTRODUCTION}

Barrett's esophagus (BE) is a premalignant condition characterized by the replacement of normal squamous epithelium of the esophagus by metaplastic columnar epithelium ${ }^{(1)}$. Although it may occur in asymptomatic patients, it is about twice as frequent in patients with symptomatic gastroesophageal reflux disease, in addition to being a risk factor for the appearance of esophageal adenocarcinoma (estimated annual incidence of $0.5 \%)^{(2)}$. Several aspects of BE have been the subject of controversy among general practitioners, surgeons, gastroenterologists, and pathologists, especially regarding diagnosis, treatment, and follow-up ${ }^{(3)}$.

Regarding diagnosis, it is fundamental to identify the columnar epithelium above the gastroesophageal junction. Barrett's esophageal metaplasia, which occurs when the squamous epithelium of the distal esophagus is replaced by mucus-secreting columnar epithelium, may be visualized by endoscopic findings associated with a biopsy that confirms the presence of columnar metapla$\operatorname{sia}^{(3,4)}$. Furthermore, there is controversy whether the presence of the caliciform cell is essential for diagnostic confirmation of $\mathrm{BE}$ since its identification is limited by the sample and the length of Barrett's epithelium ${ }^{(5)}$. This length will serve to classify BE as long when columnar metaplasia occurs which extends longitudinally through the esophagus at $\geq 3 \mathrm{~cm}$; short when $<3 \mathrm{~cm}$ and $\geq 1 \mathrm{~cm}$; and ultra-short if $<1 \mathrm{~cm}^{(6)}$.

Concerning the treatment of $\mathrm{BE}$, the aim is to establish the best conduct: a conservative (drug treatment) or an interventionist (endoscopic resections, anti-reflux surgery, esophagectomy, among others), that seek to avoid the possibility of future progression of $\mathrm{BE}$ to esophageal adenocarcinoma ${ }^{(1)}$. For clinical treatment, the most effective drugs seem to be those in the group of non-steroidal anti-inflammatory drugs (NSAIDs) and proton pump inhibitors

Declared conflict of interest of all authors: none

Disclosure of funding: no funding received.

${ }_{1}^{1}$ Universidade Federal de Santa Catarina, Departamento de Cirurgia, Florianópolis, SC, Brasil. ${ }^{2}$ Universidade Federal de Santa Catarina, Faculdade de Medicina, Florianópolis, SC, Brasil. ${ }_{3}^{3}$ Universidade Federal de Santa Catarina, Grupo de Pesquisa de Doenças do Aparelho Digestivo e Parede Abdominal, Florianópolis, SC, Brasil.

Corresponding author: Fabrissio Portelinha Graffunder. E-mail: fportelinha.g@gmail.com 
(PPIs $)^{(3)}$. NSAIDs exert their antitumoral effect via inhibition of cyclooxygenase-2, decreased cell proliferation, and increased apoptosis $^{(3)}$. PPIs, although they alter the aggression caused by acidic gastroesophageal reflux, reflux of non-acid gastric material (bile and other harmful agents) persists and may contribute to possible carcinogenesis $^{(3)}$. Therefore, it was thought that antireflux surgery (fundoplication) could be more effective than therapy using PPIs to prevent esophageal adenocarcinoma originating from BE, however, this was not proven by controlled studies that realized that antireflux surgery and treatment using PPIs were equivalent to possible oncologic prevention ${ }^{(2)}$. In addition to these options, until recently, esophagectomy was the gold standard for the treatment of $\mathrm{BE}$ with high-grade dysplasia; however, endoscopic resection and ablation techniques have evolved as alternative therapies, with fewer complications and virtually zero mortality ${ }^{(7)}$. These endoscopic therapies have been indicated even for the treatment of $\mathrm{BE}$ with low-grade dysplasia ${ }^{(1)}$.

Despite all current therapeutic options related to the treatment of $\mathrm{BE}$, there is still a need for endoscopic follow-up of these patients to find the presence of dysplasia or cancer as early as possible ${ }^{(8)}$. Although there is no strong evidence to demonstrate the true benefit of endoscopic follow-up in BE patients for the prevention of esophageal cancer, major gastroenterology societies around the world consider that the heterogeneity of this evidence makes it prudent to continue endoscopic surveillance of BE patients ${ }^{(9)}$. Societies such as the British Society of Gastroenterology, American Gastroenterological Association, and American College of Gastroenterology use the degree of dysplasia identified in endoscopy to determine the strategy of future endoscopic follow-up ${ }^{(9-12)}$, while the European Society of Gastrointestinal Endoscopy states that ultra-short BE does not require endoscopic follow-up, but short BE should perform upper gastrointestinal endoscopy (upper GI endoscopy) every 5 years and long BE should perform upper GI endoscopy every 3 years; unless it has a longitudinal extension $\geq 10 \mathrm{~cm}$. In these cases of $\mathrm{BE} \geq 10 \mathrm{~cm}$, follow-up in a specialized center for the treatment of $\mathrm{BE}$ and endoscopic follow-up is indicated, initially every 6 months ${ }^{(13)}$.

Given this panorama, the objective of this systematic review is to present the particularities and clarify controversies related to the establishment of diagnosis and treatment of BE, as well as the indication and planning of future endoscopic surveillance, based on the best evidence available today.

\section{METHODS}

\section{Search strategy}

The PRISMA protocol (Preferred Reporting Items for Systematic Reviews and Meta-Analysis) ${ }^{(14)}$ recommendations were followed for this review through research in the databases (PubMed/ Medline, Cochrane and SciELO), identifying the studies published in English and Portuguese in the last 10 years (04/25/2009 to 12/09/2019). In this search both MeSH and non-MeSH terms were included: "Barrett" (in the title) AND "diagnosis or treatment or therapy or surveillance" (in all fields). Only finished or Phase IV randomized controlled trials with individuals over 18 years of age were selected (inclusion criteria). Rare additional studies ${ }^{(1-14)}$ were used to support the information presented in the introduction and discussion, such as reviews by renowned experts and guidelines from renowned societies, to provide clarification of some hidden concepts not adequately explored in the selected clinical trials, especially regarding the presentation of recommendations on $\mathrm{BE}$ endoscopic monitoring and surveillance (information unavailable in selected clinical trials). The authors independently evaluated all selected studies and any disagreement was resolved by consensus among all. Studies that did not respect the inclusion criteria or did not have full access to all their content were excluded from the study. Pilot studies were also excluded.

\section{RESULTS}

\section{Search results}

The initial search identified 619 complete or phase IV clinical trial type studies. After the withdrawal of the duplicate studies, the inclusion/exclusion criteria were applied, an evaluation of the titles and abstracts was carried out to select those with pertinent subjects to the proposal of this review, and a full reading of these was subsequently carried out, and it was possible to identify 42 valid studies to generate possible future inferences, according to the process described in FIGURE 1.

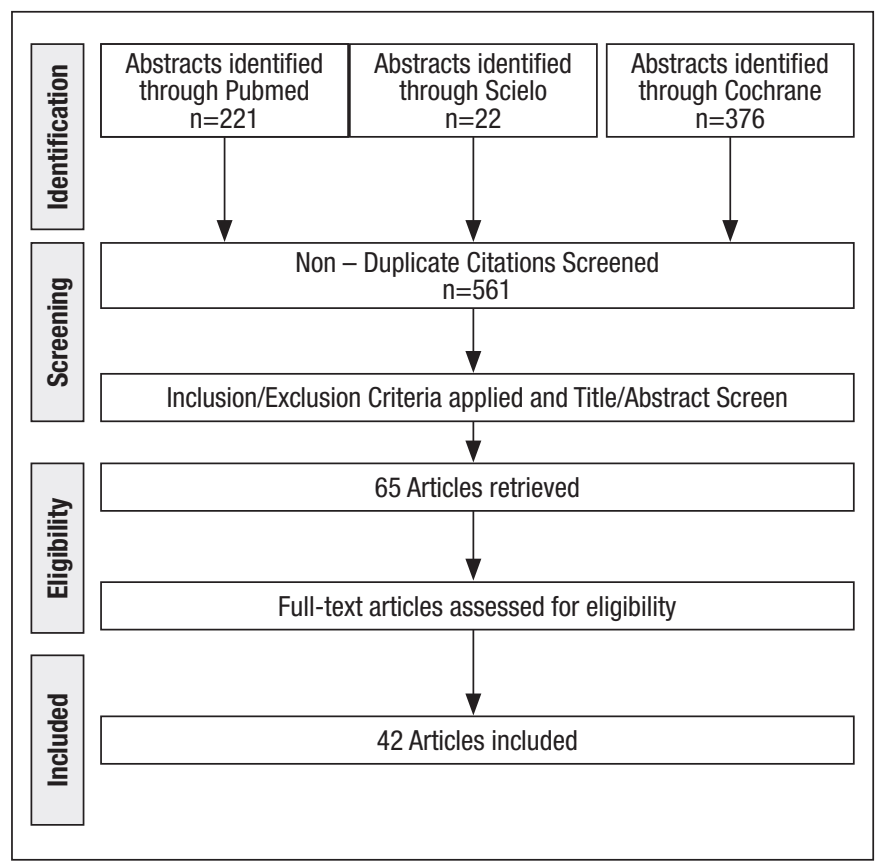

FIGURE 1. Flowchart demonstrating the search process, screening, eligibility and selection of studies.

Of the 42 studies selected, 16 were dedicated to addressing particularities related to $\mathrm{BE}$ diagnosis to improve the efficiency of endoscopic biopsies. They presented the possibility of transnasal endoscopy and the use of brushed cytology as alternatives to traditional upper GI endoscopy without the need for sedation, favoring acceptance by patients, in addition to the possibility of brushed cytology providing samples for esophageal cytology with high precision through the use of methylated DNA markers ${ }^{(15-18)}$. Transnasal endoscopy has presented capacity to completely evaluate the esophagus, both in a mobile unit $(99 \%)$ and in an outpatient setting $(96 \%)$ similar to traditional esophagogastroduodenoscopy $(100 \%)(P=0.08)^{(16)}$ whereas brushed cytology showed $100 \%$ specificity and $100 \%$ sensitivity $(95 \% \mathrm{CI}=82-100)$ in the detection of $\mathrm{EB}$ with the markers VAV3 and ZNF682 $2^{(18)}$. 
The establishment of the Seattle protocol (which recommends biopsies every $2 \mathrm{~cm}$ in the four quadrants of the esophageal lumen) was also highlighted ${ }^{(19,20)}$. However, it is valid to inform that biopsy protocols directed by the application of dyes to improve the delimitation of Barrett's epithelium, such as that using acetic acid (Portsmouth Protocol ${ }^{(21)}$ ), can reduce the number of biopsies needed to identify neoplastic cells, since dye guided biopsy has been shown to identify a significantly higher proportion of collected samples $(62 \%)$ containing specialized columnar epithelium when compared to the Seattle protocol $(24 \%)(P<0.0001)^{(22)}$. Despite this, there is no difference in the identification of high-grade dysplasia and cancer when compared to the Seattle protocol (not directed by dyes) ${ }^{(22)}$. In addition, Narrow Banding Imaging biopsies have the same rate of detection of intestinal metaplasia as methods using high-definition white light associated with the Seattle protocol $(92 \%$ detection rate), requiring fewer biopsies to achieve diagnostic goals (3.6 vs 7.6, $P<0.0001)^{(23)}$. Moreover, the addition of techniques such as confocal laser endomicroscopy, which combines endoscopy and microscopic imaging of the gastrointestinal mucosa ${ }^{(24-30)}$, may increase the detection rate of high-grade dysplasia or adenocarcinoma when compared with the Seattle protocol $(33.7 \%$ vs $17.2 \%$ positive biopsies for high grade dysplasia or cancer, $P<0.0001)^{(24-26,29,30)}$, although there is as yet no evidence that the addition of this method to detect residual BE or neoplasia will promote better treatment for patients with $\mathrm{BE}$ in the future(28).

Twenty-six studies addressed properties related to the treatment of BE, mainly related to types of ablative endoscopic therapies.

Some considerations are worth highlighting:

There are no recommendations presented by the main international gastroenterology societies published before 2018 that consolidated the value of chemoprophylaxis, with PPI-type medications associated with acetylsalicylic acid (ASA) to reduce neoplastic progression in patients with Barrett's esophagus, although there is identification of good results demonstrated by some studies from 2018 onwards, which drive the need to review this topic ${ }^{(31,32)}$. For example, the AsPECT study published in 2018 demonstrated that the use of esomeprazole $40 \mathrm{mg}$ 2x/day and ASA $300 \mathrm{mg} /$ day statistically significantly and safely improves the expected oncologic outcomes for BE patients when compared to patients taking lowdose esomeprazole (20 mg 1x/day) and without aspirin (TR 1.59, 95\% CI 1.14-2.23, $P=0.0068)^{(32)}$.

The treatment of $\mathrm{BE}$ patients with esomeprazole in high doses, but not with pantoprazole, seems to promote a decrease in proliferative markers, concomitantly with a decrease in cell death by apoptosis $(P<0.05)^{(33)}$. Also, esomeprazole has enabled better control of esophageal acid than pantoprazole (24-hour metric $\mathrm{pH}$ with ph $<4$ in $2.5 \pm 1.1 \%$ vs $3.9 \pm 1.5 \%$ of time, $P<0.05)^{(33)}$.

Although the types of resecting endoscopic treatments (resection of the mucosa or submucosa of the esophagus by endoscopic route) present a similar safety index, submucosa dissection presents higher rates of complete histological resection (58\% vs $11.7 \%$, $P=0.01)$, although it is more time consuming ( $54 \pm 33$ vs $22 \pm 13$ $\min , P=0.0002)$ and has a higher risk of serious complications $(2 \%$ vs $0 \%, P=0.49$ ) such as perforation and large bleeding during the procedure which required blood transfusion ${ }^{(34,35)}$.

The multiband mucosectomy technique is cheaper and faster (34 vs $50 \mathrm{~min}, P=0.02$ ) and is not associated with a higher number of perforations $(0.02 \%$ vs $0.07 \%, P<0.001)$ than the fragmented endoscopic resection of early neoplasia identified in Barrett's epithelium ${ }^{(36)}$.
As for ablative therapies (techniques that use thermal, photochemical, or radiofrequency energy to remove the abnormal epithelium) ${ }^{(37-55)}$, endoscopic radiofrequency ablation (RFA) has significantly reduced neoplastic progression (the annual rate of $1.37 \%$ /patient-years ${ }^{(38)}$ ), especially when compared to some endoscopic surveillance programs ${ }^{(39-42)}$, including giving these patients the impression and prospects of a less threatening view of $\mathrm{BE}^{(40)}$.

Simplified focal RFA regimens, in which three ablations are performed at $12 \mathrm{~J} / \mathrm{cm}^{2}$, without cleaning the ablation zone, are not inferior in achieving complete endoscopic and histological regression of intestinal dysplasia and metaplasia to the standard focal RFA regimen (two ablations at $15 \mathrm{~J} / \mathrm{cm}^{2}$, followed by cleaning the ablation zone and removal of the catheter to clean the electrode, followed by reintroduction for two more ablations at $\left.15 \mathrm{~J} / \mathrm{cm}^{2}\right)(74 \%$ vs $83 \%, P=0.34)$, and the simplified regimens are associated with a significantly shorter procedure time (13 vs $20 \mathrm{~min}, P<0.0001)^{(43-47)}$.

When comparing the safety of radical endoscopic resection with RFA for BE cases $\leq 5 \mathrm{~cm}$, although both techniques presented high remission rate of intestinal metaplasia and/or neoplasia ( $100 \%$ vs $96 \% P=0.47)$, endoscopic resection presented a higher number of severe complications $(24 \%$ vs $0 \%, P=0.02)$ and a higher number of necessary therapeutic sessions (6 [range 1-20] vs 3 [range $1-8$ ] $P=0.00)^{(37)}$.

Argon plasma coagulation (APC) has been studied as a cheaper and possibly as a safe and effective alternative to RFA, however, a study is still needed to demonstrate its non-inferiority to $\mathrm{RFA}^{(48-53)}$.

RFA is the preferred ablative minimally invasive therapy for endoscopic BE treatment due to lower efficacy and less standardization of other therapies (such as $\mathrm{APC}^{(48-53)}$ and photodynamic therapy which have recurrence rates greater than $50 \%$ in 2 years vs $8 \%$ recurrence in 5 years of the $\mathrm{RFA}^{(54,55)}$ )

There is evidence that a systematic physical exercise program can help prevent oncogenesis of patients with $\mathrm{BE}$ by reducing abdominal circumference $(-4.5 \mathrm{~cm}[95 \% \mathrm{CI}-7.5,-1.4]$ in 24 weeks; $P<0.01)$ and leptin concentrations $(-3 \mathrm{ng} / \mathrm{mL}[-6.6,0.6]$, in 24 weeks $P=0.09)$, important risk factors for esophageal adenocarcinoma ${ }^{(56)}$.

Endoscopic follow-up of low-grade BE patients seems safe if treated with RFA sessions, with an eradication rate and no progression to high-grade dysplasia/adenocarcinoma close to $100 \%$, in 6 years of follow-up ${ }^{(39)}$. Nevertheless, studies still need to be conducted to refine the intervals between RFA sessions ${ }^{(39)}$.

\section{DISCUSSION}

Alternative methods to traditional sedated esophagogastroduodenoscopy (sEGD) for the detection of BE have been studied in the last decade ${ }^{(15-18)}$. Transnasal endoscopy without sedation, although having greater patient acceptance, effectiveness, and safety similar to SEGD, has its use in the diagnosis and surveillance of BE still limited by its inferior ability to acquire successful biopsies ${ }^{(16)}$. As for the use of brushed cytology, which consists of swallowing a gelatine-encapsulated sponge attached to a string, which may provide esophageal cytology samples capable of detecting BE in a minimally invasive, well-tolerated and with high precision through methylated DNA markers, associated with the possibility of discriminating patients with and without BE with biomarkers, allows the early detection of BE and adenocarcinoma, which may lead to a greater number of patients with need for follow-up ${ }^{(18)}$. 
Mandatory or not, presence of caliciform cells in the histological study for confirmation of the diagnosis of $\mathrm{BE}$ is still a matter of controversy among the main gastroenterology societies in the world. For the American Society of Gastroenterology, the American College of Gastroenterology and the European Society of Gastrointestinal Endoscopy, the presence of the caliciform cell is mandatory to establish the diagnosis of $\mathrm{BE}$, since it will generate, when compared to the absence of the caliciform cell, a greater annual risk of malignancy of $\mathrm{BE}(0.38 \% \text { vs } 0.07 \% \text { when the caliciform cell is absent })^{(11-13)}$. On the other hand, for the British Society of Gastroenterology, the histological criterion for the diagnosis of $\mathrm{BE}$ requires only the presence of columnar metaplasia, regardless of the presence or absence of the caliciform cell, which is justified by mentioning that a single endoscopy, with a reduced number of biopsies (collection of fewer than eight samples) is not sufficient to exclude the presence of caliciform cells, especially in patients with short BE, which may let those with malignancy potential go unnoticed, and as a consequence leave them without adequate endoscopic follow-up ${ }^{(10)}$.

The latest endoscopic surveillance techniques to enhance the detection of dysplastic BE include dye-based chromoendoscopy, Narrow Banding Imaging (NBI), confocal laser endomicroscopy and Wide-area trans-epithelial (WATS) with computer-aided threedimensional analysis ${ }^{(19-30)}$. The use of chromoendoscopy with acetic acid, which involves the application of this dye during the endoscopic examination, promoting the enhancement of the characteristics of the mucosal surface, improving the diagnostic evaluation and targeting of biopsies in BE; and NBI, which is a computerized virtual chromoscopy method that uses optical filters to isolate the blue and green wavelengths, facilitating the visualization of changes in the superficial mucosa and its vasculature in real time, seem to significantly reduce the number of biopsies necessary to establish the diagnosis of Barrett's epithelium with precision ${ }^{(21-23)}$. The WATS sampling method, on the other hand, has been shown to increase the detection of high-grade dysplasia and adenocarcinoma in two multicenter randomized clinical trials ${ }^{(19,20)}$. As for the use of confocal laser endoscopy, although it increases the detection of dysplasia and adenocarcinoma, there is no evidence that endoscopists with minimal experience in this technique can use this technology sensitively and accurately to detect dysplasia ${ }^{(27)}$.

Concerning the implications of the size of the segment affected by Barrett's epithelium, some gastroenterology societies discourage biopsies of ultra-short $\mathrm{BE}$, since there is no clear consensus on the management of these patients and previous studies suggest that the rate of progression of ultra-short $\mathrm{BE}$ to adenocarcinoma is low (about 0.1 per 1000 patients) $)^{(13,57)}$. None of the randomized clinical trials selected in this study focused on this controversy. However, a recent study found a high prevalence of dysplasia in ultra-short Barrett (15.8\%), with no statistically significant difference when compared with the prevalence of dysplasia in patients with short and long term BE together (22.2\%), which casts doubt on the conduct of underestimating the carcinogenic potential of ultra-short $\mathrm{BE}^{(57)}$.

Controversy exists regarding chemoprophylaxis in BE with the use of high doses of PPI and associations with acetylsalicylic acid, however, consensus published in the United Kingdom and North America before 2018 recommended that the lowest effective dose to control reflux symptoms would already be sufficient ${ }^{(11,58)}$. However, the AsPECT study with 2557 patients followed up for 8.9 years, published in 2018 , showed that esomeprazole $40 \mathrm{mg}$ (twice a day) and ASA $300 \mathrm{mg} /$ day therapy, especially when as- sociated, improved in a statistically significant and safe way that the outcomes (prognosis and progression to high-grade dysplasia or esophageal adenocarcinoma) expected for patients with $\mathrm{BE}^{(32)}$. Few limitations occur in this study ${ }^{(32)}$, which included: mostly white sampling (impairing extrapolation of results for other ethnic groups) and consisting of only 500 women $^{(32)}$. However, this was the first and largest randomized study ever conducted to evaluate chemoprophylaxis with PPI and ASA in BE, and its results may be added to the reasons for a future review of current guidelines that address this issue ${ }^{(32)}$. With respect to the use of NSAIDs other than ASA, there are still no randomized clinical trials that have shown a reduced risk of malignant Barrett's epithelium ${ }^{(11)}$.

Anti-reflux surgery is an alternative to treatment with PPIs to correct lower esophageal sphincter dysfunction, controlling gastroduodenoesophageal reflux in $89 \%-90 \%$ of patients, with no statistically significant difference in progression to esophageal adenocarcinoma when compared to the use of PPIs ${ }^{(58)}$. However, even patients with a low risk of surgical complications and who prefer to avoid the use of medications should be advised that the use of PPIs for long-term acid suppression will be necessary even after antireflux surgery ${ }^{(58)}$.

The use of alternative techniques to RFA for treatment of $\mathrm{BE}$ such as APC still requires technical improvement and can be used in cases of small islands of BE residual to previous RFA sessions ${ }^{(59)}$.

Due to the high chance of $\mathrm{BE}$ with high-grade dysplasia evolving into adenocarcinoma, eradication of dysplastic epithelium is recommended, and the use of RFA after focal endoscopic resection is safer than endoscopic resection in consecutive sessions with intervals of 6 to 8 weeks, with a maximum of four sessions, in case of BE less than or equal to $5 \mathrm{~cm}$ due to the lower occurrence of post-procedural complications, such as perforation and esophageal stenosis ${ }^{(37)}$. These complications will likely occur even more if endoscopic resection alone is used to treat BE larger than $5 \mathrm{~cm}$, and RFA also appears to be more effective in the treatment of high-grade dysplasia in patients with $\mathrm{BE}$ larger than or equal to $10 \mathrm{~cm}^{37,60)}$.

Only one randomized clinical trial addressed a possible nondrug therapy complementary to $\mathrm{BE}$ treatment ${ }^{(5)}$. This trial investigated the feasibility and safety of establishing 24 -week exercise programs in men with BE compared to a control group ${ }^{(56)}$. It attempted to establish the risk factors associated with the development of esophageal adenocarcinoma to demonstrate that although no statistically significant differences were observed, it evidenced that the group that participated in the exercise program had decreased leptin and decreased abdominal waist circumference, these factors being related to the prevention of the evolution of Barrett's epithelium into esophageal adenocarcinoma, although it stated that further studies are still needed to establish adequate evidence and knowledge about the real effect of exercise on the prevention of esophageal adenocarcinoma ${ }^{(56)}$.

As for the endoscopic follow-up of BE, there is still disagreement between the protocols of the main gastroenterology societies in the world, such as the British Society of Gastroenterology (BSG), American Gastroenterological Association (AGA), American College of Gastroenterology (ACG) and European Society of Gastrointestinal Endoscopy (ESGE) ${ }^{(10,13)}$. The surveillance and endoscopic follow-up intervals in BE, recommended by the BSG, AGA, and ACG societies, have their risk stratification established by the presence and degree of dysplasia; contrary to the ESGE, which only recognizes the importance of the length of the followup affected by BE (FIGURE 2). 


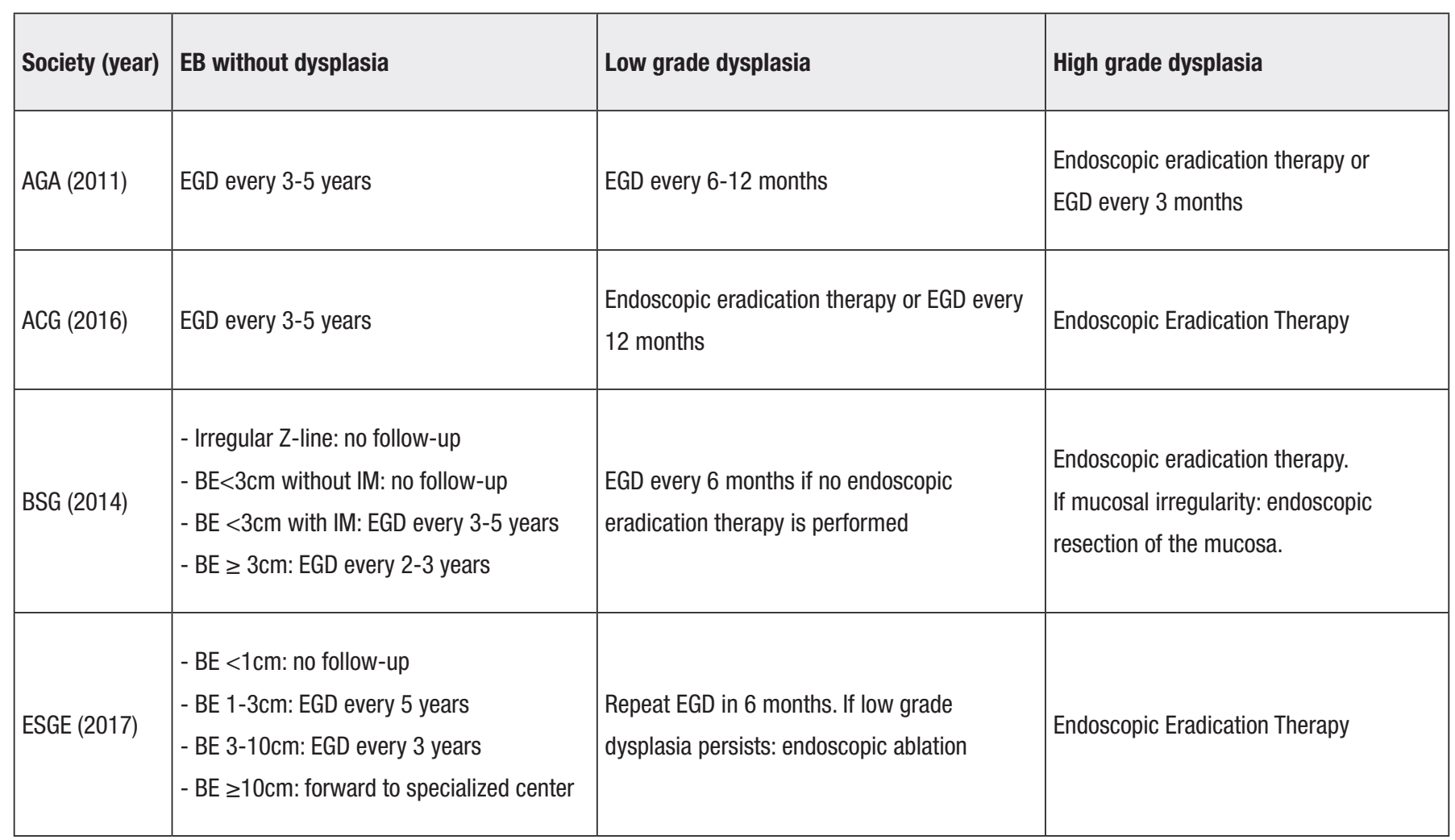

FIGURE 2. Endoscopic follow-up protocols for Barrett's esophagus.

AGA: American College of Gastroenterology; ACG: American College of Gastroenterology; BSG: British Society of Gastroenterology; ESGE: European Society of Gastrointestinal Endoscopy; EGD: esophagogastroduodenoscopy; IM: intestinal metaplasia; BE: Barrett's esophagus.

Finally, new techniques have been studied to improve the detection of dysplastic $\mathrm{BE}$ and reduce the number of biopsies required, as well as to reduce the time and increase patient acceptance (endoscopic procedure performed through nasal access) of endoscopic procedures, especially ablation, with electronic chromoscopic techniques such as Narrow Band Imaging being the most recommended for this goal. The RFA remains the golden standard for the elimination of Barrett's esophagus due to lower recurrence rates and fewer complications associated with the procedure.

Due to the risk of recurrence of dysplasia after ablation, new studies recommend the use of high-dose esomeprazole and ASA as continuous chemoprophylaxis for life, in addition to lifelong follow-up of patients with short and long term BE, after treatment with RFA, unless it has limiting comorbidities that in the future contraindicate a possible esophagectomy. Unfortunately, there are no randomized controlled trials that have evaluated which is the best recommendation for BE follow-up and endoscopic surveillance $(>1$ $\mathrm{cm}$ ) protocols, however, based on current International Guidelines, it is recommended EGD every 5 years in BE without dysplasia with 1 up to $3 \mathrm{~cm}$ of extension; every 3 years in BE without dysplasia with $>3$ up to $10 \mathrm{~cm}$ of extension, every 6 to 12 months in BE with low grade dysplasia and, finally, EGD every 3 months after ablative endoscopic therapy in cases of $\mathrm{BE}$ with high grade dysplasia.

\section{Authors' contribution}

All authors contributed with data collection, research execution and text writing.

\section{Orcid}

José Roberto Alves: 0000-0002-0520-5190.

Fabrissio Portelinha Graffunder: 0000-0002-0224-846X.

João Vitor Ternes Rech: 0000-0003-2638-2169.

Caique Martins Pereira de Moura Ternes: 0000-0001-8389-2574. Iago Koerich Silva: 0000-0003-1330-5324. 
Alves JR, Graffunder FP, Rech JVT, Ternes CMP, Koerich Silva I. Diagnóstico, tratamento e seguimento do esôfago de Barrett: revisão sistemática. Arq Gastroenterol. 2020;57(3):289-95.

RESUMO - Contexto - O esôfago de Barrett (EB) é uma condição que aumenta o risco de ocorrência de displasias e câncer no esôfago, a qual apresenta inúmeras controvérsias entre médicos generalistas e até especialistas, em especial no que tange o seu diagnóstico, tratamento e seguimento. Objetivo - Tentar esclarecer as controvérsias relacionadas ao estabelecimento do diagnóstico, tratamento, seguimento e vigilância do EB. Métodos - Foi realizado revisão sistemática da literatura fundamentada apenas em ensaios clínicos randomizados e controlados (completos ou em fase IV), em indivíduos maiores que 18 anos, publicados nos últimos 10 anos, por meio de busca, nas bases de dados: PubMed, Cochrane e SciELO (utilizando os termos MeSH e não-MeSH: "Barrett" no título AND diagnosis or treatment or therapy or surveillance" em todos os campos). Resultados - Um total de 42 ensaios clínicos controlados e randomizados foram identificados e selecionados após aplicação dos critérios de inclusão e exclusão. Evidenciou-se, principalmente, o surgimento de técnicas seguras, alternativas à endoscopia digestiva alta (EDA) tradicional para aprimorar a detecção do esôfago de Barrett, associadas a boa aceitação por parte dos pacientes, quando realizadas por meio de acesso nasal. Ainda, o uso de protocolo de biópsias guiadas por cromoendoscopia eletrônica favoreceu reduzir significativamente o número de biópsias necessárias para alcançar as melhores taxas de identificação histológica do EB. Ademais, foi evidenciado que o uso de esomeprazol $40 \mathrm{mg} 2 \mathrm{x} /$ dia associado ao ácido acetil salić́lico $300 \mathrm{mg} /$ dia pode ter efeito protetivo em relação ao desenvolvimento de câncer no EB, além de ser identificado protocolos de seguimento e vigilância endoscópica dos pacientes com EB $>1 \mathrm{~cm}$ fundamentados, especialmente, no grau de displasia e comprimento do EB (EB sem displasia com 1 a $3 \mathrm{~cm}=$ EDA a cada 5 anos; EB sem displasia com $>3$ a $10 \mathrm{~cm}=$ EDA a cada 3 anos; EB com displasia de baixo grau = EDA a cada 6 a 12 meses; EB com displasia de alto grau = realização de terapia endoscópica ablativa e EDA a cada 3 meses). Conclusão - Foi verificado a necessidade do desenvolvimento de mais ensaios clínicos randomizados e controlados relacionados ao tema, especialmente no que tange o estabelecimento do seguimento e vigilância do EB, entretanto, na luz das melhores evidências apresentadas na última década, o diagnóstico de EB deve seguir, idealmente, protocolos de biópsias guiadas por cromoendoscopia eletrônica. Ademais, o tratamento deve ser fundamentado primeiramente em técnicas endoscópicas, especialmente aquelas terapias com radiofrequência, e quando associado a displasia de alto grau, deverá ser ponderado quanto aos riscos de se insistir em métodos endoscópicos ablativos ou considerar um tratamento cirúrgico ressectivo. Por fim, reforça-se a necessidade de todo paciente com EB $>1 \mathrm{~cm}$ permanecer em seguimento endoscópico por toda a sua vida, conforme protocolos pré-estabelecidos, exceto se apresentar comorbidades limitantes que impediriam a realização de alguma conduta mais intervencionista. Infelizmente, não há ensaios clínicos randomizados que avaliaram qual é a melhor recomendação de protocolo para o seguimento endoscópico de EB (>1cm), porém, baseado nas atuais Guidelines Internacionais, é recomendado esofagogastroduodenoscopia (EGD) a cada 5 anos em EB sem displasia com 1 a $3 \mathrm{~cm}$ de extensão; a cada 3 anos em EB com displasia com 3 a $10 \mathrm{~cm}$ de extensão, a cada 6 a 12 meses em EB com displasia de baixo grau e, finalmente, EGD a cada 3 meses após terapia ablativa endoscópica nos casos de EB com displasia de alto grau.

DESCRITORES - Esôfago de Barrett, patologia. Esofagoscopia, métodos. Biópsia guiada por imagem, métodos. Carcinogênese. Metaplasia.

\section{REFERENCES}

1. Splittgerber, M, Velanovich, V. Barrett Esophagus. Surg Clin North Am. 2015;95:593-604.

2. Estores D, Velanovich, V. Barrett esophagus: epidemiology, pathogenesis, diagnosis, and management. Curr Probl Surg. 2013;50:192-226.

3. Spechler SJ, Sharma P, Souza RF, Inadomi JM, Shaheen NJ. American Gastroenterological Association Technical Review on the Management of Barrett's Esophagus. Gastroenterology. 2011;140:e18-e52.

4. Boyce HW. Endoscopic definitions of esophagogastric junction regional anatomy. Gastrointest Endosc. 2000;51:586-92.

5. Oberg S, Johansson J, Wenner J, Johnsson F, Zilling T, von Holstein CS, et al. Endoscopic surveillance of columnar-lined esophagus: frequency of intestina metaplasia detection and impact of antireflux surgery. Ann. Surg. 2001;234;619-26

6. Pohl H, et al. Length of Barrett's oesophagus and cancer risk: implications from a large sample of patients with early oesophageal adenocarcinoma. Gut. 2016;65:196-201.

7. Spechler SJ, Souza RF. Barrett's Esophagus. N Engl J Med. 2014;371:836-45. DOI: 10.1056/NEJMra1314704

8. Whiteman DC, Appleyard M, Bahin FF, Bobryshev YV, Bourke MJ, Brown I, et al. Australian clinical practice guidelines for the diagnosis and management of Barrett's esophagus and early esophageal adenocarcinoma. J Gastroenterol Hepatol. 2015;30:804-20.

9. Dunbar KB, Spechler SJ. Controversies in Barrett Esophagus. Mayo Clin Proc. 2014;89:973-84.

10. Fitzgerald RC, di Pietro M, Ragunath K, Ang Y, Kang JY, Watson P, et al. British Society of Gastroenterology guidelines on the diagnosis and management of Barrett's oesophagus. Gut. 2014;63:7-42.

11. Shaheen NJ, Falk GW, Iyer PG, Gerson LB. ACG Clinical Guideline: Diagnosis and Management of Barrett's Esophagus. Am J Gastroenterol. 2016;111:30-50

12. Spechler SJ, Sharma P, Souza RF, Inadomi JM, Shaheen NJ. American Gastroenterological Association Medical Position Statement on the Management of Barrett's Esophagus. Gastroenterology. 2011;140:1084-91.

13. Weusten B, Bisschops R, Coron E, Dinis-Ribeiro M, Dumonceau JM, Esteban JM, et al. Endoscopic management of Barrett's esophagus: European Society of Gastrointestinal Endoscopy (ESGE) Position Statement. Endoscopy. 2017;49:191-8.
14. Moher D, Shamseer L, Clarke M, Ghersi D, Liberati A, Petticrew M, et al Preferred reporting items for systematic review and meta-analysis protocols (PRISMA-P) 2015 statement. Syst. Rev. 2015;4:1.

15. Wang KK, Brankley SM, Prasad GA, Song LMWK, Buttar N, Fritcher EB, et al. Prospective Randomized Controlled Trial of Biomarkers to Predict Response to Ablation Therapy in Barrett's Esophagus (BE) with High Grade Dysplasia (HGD). Gastroenterology. 2009;136. DOI: https://doi.org/10.1016/S00165085(09)60709-5

16. Sami SS, Dunagan KT, Johnson ML, Schleck CD, Shah ND, Zinsmeister AR, et al. A Randomized Comparative Effectiveness Trial of Novel Endoscopic Techniques and Approaches for Barrett's Esophagus Screening in the Community: Am J Gastroenterol. 2015;110:148-58.

17. Iyer P, Johnson M, Lansing R, Yab TC, Taylor WR, Slettedahl SW, et al. Assessment of Sponge-on-String Device Parameters for the Non-endoscopic Detection of Barrett's Esophagus: Results from a Randomized Trial: 2016 ACG Presidential Poster Award. Am J Gastroenterol. 2016;111:S229.

18. Iyer PG, Taylor WR, Johnson ML, Lansing RL, Maixner KA, Yab TC, et al Highly Discriminant Methylated DNA Markers for the Non-endoscopic Detection of Barrett's Esophagus: Am J Gastroenterol. 2018;113:1156-66.

19. Vennalaganti PR, Kaul V, Wang KK, Falk GW, Shaheen NJ, Infantolino A, et al. Increased detection of Barrett's esophagus-associated neoplasia using wide-area trans-epithelial sampling: a multicenter, prospective, randomized trial. Gastrointest Endosc. 2018;87:348-55.

20. Vennalaganti P, et al. Sa1891 Increased Detection of Barrett's Esophagus (BE)-Associated Neoplasia Using Wide-Area Trans-Epithelial Sampling in Conjunction With 4-Quadrant Biopsies: Interim Results From a Multi-Center, Prospective, Randomized Trial. Gastroenterology. 2015;148:S-348. DOI: 10.1016/ S0016-5085(15)31165-3

21. Longcroft-Wheaton G, Bhandari P. Acetic Acid Guided Biopsies Versus Mapping Biopsies For Barrett's Surveillance: The Abba Study. EMJ Gastroenterol. 2018:7:80-1.

22. Hoffman A, Korczynski O, Tresch A, Hansen T, Rahman F, Goetz M, et al Acetic acid compared with i-scan imaging for detecting Barrett's esophagus: a randomized, comparative trial. Gastrointest. Endosc. 2014;79:46-54. 
23. Sharma P, Hawes RH, Bansal A, Gupta N, Curvers W, Rastogi A, et al. Standard endoscopy with random biopsies versus narrow band imaging targeted biopsies in Barrett's oesophagus: a prospective, international, randomised controlled trial. Gut. 2013;62:15-21.

24. Canto MI, Anandasabapathy S, Brugge W, Falk GW, Dunbar KB, Zhang Z, et al. In vivo endomicroscopy improves detection of Barrett's esophagus-related neoplasia: a multicenter international randomized controlled trial (with video). Gastrointest Endosc. 2014;79:211-21

25. Lee MH, Parikh N, Polydorides AD, Louie J, Protano MA, Mitcham J, et al. Diagnostic Yield and Clinical Impact of a Low-Cost Microendoscope in the Early Diagnosis of Barrett's Associated Neoplasia: A Prospective, Single-Center Randomized Controlled Trial. Gastroenterology. 2014;146:S-522.

26. Canto MI, Anandasabapathy S, Falk G, Brugge WR, Dunbar KB, Woods KE, et al. In Vivo Endoscope-Based Confocal Laser Endomicroscopy (eCLE) Improves Detection of Unlocalized Barrett's Esophagus-Related Neoplasia Over High Resolution White Light Endoscopy: an International Multicenter Randomized Controlled Trial. Gastrointest. Endosc. 2012;75:AB174. DOI: 10.1016/j. gie.2012.04.151.

27. Nguyen VX, Nguyen CC, De Petris G, Sharma VK, Das A. Confocal endomicroscopy (CEM) improves efficiency of Barrett surveillance. J Interv Gastroenterol. 2012;2:61-5.

28. Wallace MB, Crook JE, Saunders M, Lovat L, Coron E, Waxman I, et al. Multicenter, randomized, controlled trial of confocal laser endomicroscopy assessment of residual metaplasia after mucosal ablation or resection of GI neoplasia in Barrett's esophagus. Gastrointest. Endosc. 2012;76:539-47.e1

29. Sharma P, Meining AR, Coron E, Lightdale CJ, Wolfsen HC, Bansal A, et al. Real-time increased detection of neoplastic tissue in Barrett's esophagus with probe-based confocal laser endomicroscopy: final results of an international multicenter, prospective, randomized, controlled trial. Gastrointest Endosc. 2011;74:465-72.

30. Dunbar KB, Okolo P, Montgomery E, Canto MI. Confocal laser endomicroscopy in Barrett's esophagus and endoscopically inapparent Barrett's neoplasia: a prospective, randomized, double-blind, controlled, crossover trial. Gastrointest. Endosc. 2009;70:645-54.

31. Falk GW, Buttar NS, Foster NR, Ziegler KLA, Demars CJ, Romero Y, et al A Combination of Esomeprazole and Aspirin Reduces Tissue Concentrations of Prostaglandin E2 in Patients With Barrett's Esophagus. Gastroenterology. 2012;143:917-26.el.

32. Jankowski JAZ, Caestecker J, Love SB, Reilly G, Watson P, Sanders S, et al. Esomeprazole and aspirin in Barrett's oesophagus (AspECT): a randomised factorial trial. The Lancet. 2018;392:400-8.

33. de Bortoli N, Martinucci I, Piaggi P, Maltinti S, Bianchi G, Ciancia E, et al. Randomised clinical trial: twice daily esomeprazole $40 \mathrm{mg}$ vs. pantoprazole $40 \mathrm{mg}$ in Barrett's oesophagus for 1 year: Randomised clinical trial: double-dose PPI in patients with Barrett's oesophagus. Aliment. Pharmacol. Ther. 2011;33:1019-27.

34. Terheggen G, Rutz EM, Vieth M, Schumacher B, Neuhaus H. 216 a Prospective Randomized Controlled Trial on Endoscopic Mucosal Resection (EMR) Versus Water-Jet Assisted Endoscopic Submucosal Dissection (WESD) for Early Barrett's Neoplasia. Gastrointest Endosc. 2015;81:AB126-AB127. DOI: https://doi org/10.1016/j.gie.2015.03.035

35. Terheggen G, Horn EM, Vieth M, Gabbert H, Enderle M, Neugebauer A, et al. A randomised trial of endoscopic submucosal dissection versus endoscopic mucosal resection for early Barrett's neoplasia. Gut. 2017;66:783-93.

36. Pouw RE, van Vilsteren FGI, Peters FP, Herrero LA, Kate FJWT, Visser M, et al. Randomized trial on endoscopic resection-cap versus multiband mucosectomy for piecemeal endoscopic resection of early Barrett's neoplasia. Gastrointest. Endosc. 2011;74:35-43

37. van Vilsteren FG, Pouw RE, Seewald S, Alvarez Herrero L, Sondermeijer CM, Visser M, et al. Stepwise radical endoscopic resection versus radiofrequency ablation for Barrett's oesophagus with high-grade dysplasia or early cancer: a multicentre randomised trial. Gut. 2011;60:765-73

38. Shaheen NJ, Overholt BF, Sampliner RE, Wolfsen HC, Wang KK, Fleischer DE, et al. Durability of Radiofrequency Ablation in Barrett's Esophagus With Dysplasia. Gastroenterology. 2011;141:460-8.

39. Klaver E, Phoa KN, Weusten BLAM, Vilsteren FGV, Bisschops R, Schoon EJ, et al. Long-term follow-up results of a randomized trial comparing radiofrequency ablation versus endoscopic surveillance in Barrett's esophagus patients with low-grade dysplasia. Gastrointest. Endosc. 2018;87:AB83. DOI: 10.1016/j. gie.2018.04.090.

40. Rosmolen W, Phoa KYN, Weusten BLAM, Nieuwkerk PT, Schoon EJ, Bisschops $\mathrm{R}$, et al. Impact of Ablation vs. Surveillance on Quality of Life and Illness Perception in Patients With Barrett's Esophagus Containing Low-Grade Dysplasia A Multi-Center Randomized Controlled Trial. Gastroenterology. 2014;46:S-564. DOI: 10.1016/S0016-5085(14)62045-X.
41. Phoa KN, van Vilsteren FGI, Weusten BLAM, Bisschops R, Schoon EJ, Ragunath $\mathrm{K}$, et al. Radiofrequency Ablation vs Endoscopic Surveillance for Patients With Barrett Esophagus and Low-Grade Dysplasia: A Randomized Clinical Trial. JAMA. 2014;311:1209.

42. Phoa KYN, van Vilsteren FG, Pouw RE, Weusten BL, Schoon EJ, Bisschops R, et al. Radiofrequency Ablation in Barrett's Esophagus With Confirmed Low-Grade Dysplasia: Interim Results of a European Multicenter Randomized Controlled Trial (SURF). Gastroenterology. 2013;144:S-187. DOI: https://doi.org/10.1016/ S0016-5085(13)60662-9

43. Pouw RE, Künzli H, Bisschops R, Sondermeijer CM, et al. A Randomized, Controlled Trial Comparing a Simplified and Standard Regimen for Focal Radiofrequency Ablation Treatment of Dysplastic Barrett's Esophagus. Gastrointest. Endosc. 2017;85:AB122. DOI: 10.1016/j.gie.2017.03.201.

44. Pouw RE, Künzli HT, Bisschops R, Sondermeijer CM, Koch AD, Didden P, et al. Simplified versus standard regimen for focal radiofrequency ablation of dysplastic Barrett's oesophagus: a multicentre randomised controlled trial. Lancet Gastroenterol. Hepatol. 2018;3:566-74.

45. van Vilsteren FGI, Phoa KN, Herrero LA, Pouw RE, Sondermeijer CMT, Visser $\mathrm{M}$, et al. A simplified regimen for focal radiofrequency ablation of Barrett's mucosa: a randomized multicenter trial comparing two ablation regimens. Gastrointest. Endosc. 2013;78:308.

46. van Vilsteren FG, Herrero LA, Phoa KYN, Pouw R, Visser M, Kate FT, et al. A Multicenter Randomized Trial Comparing Two Ablation Regimens for Focal Radiofrequency Ablation of Barrett's Mucosa Using the HALO90 System. Gastroenterology. 2012;142:S-1038. DOI: 10.1016/S0016-5085(12)64028-1.

47. Vilsteren FGV, Herrero LA, Pouw RE, Phoa KYN, Sondermeijer C, Van Lijnschoten G, et al. Simplifying Radiofrequency Ablation of Barrett's Esophagus: a Randomized Multicenter Trial Comparing Three Different Treatment Regimens for Circumferential Ablation Using the HALO 360 System. Gastrointest. Endosc. 2012;75:AB158. DOI: https://doi.org/10.1016/j.gie.2012.04.112

48. Wani SB, Gupta N, Domit B, Chuang KY, Gaddam S, Singh V, et al. Durability of Ablative Therapies in Barrett's Esophagus (BE): Long Term Results of a Randomized Controlled Trial (RCT) of Ablation With Argon Plasma Coagulation (APC) and Multipolar Electrocoagulation (MPEC). Gastroenterology. 2010;138:S-333-S-334

49. Saligram S, Tofteland N, Wani S, Gupta N, Mathur S, Vennalaganti P, et al. Long-term results of the mucosal ablation of Barrett's esophagus: efficacy and recurrence. End Int Open. 2015;3:E189-E194.

50. Bright T, Watson DI, Tam W, Game PA, Ackroyd R, Devitt PG, et al. Prospective Randomized Trial of Argon Plasma Coagulation Ablation Versus Endoscopic Surveillance of Barrett's Esophagus in Patients Treated with Antisecretory Medication. Dig Dis Sci. 2009;54:2606-11

51. Sie C, Bright T, Schoeman M, Game P, Tam W, Devitt P, Watson D. Argon plasma coagulation ablation versus endoscopic surveillance of Barrett's esophagus: late outcomes from two randomized trials. Endoscopy. 2013;45:859-65.

52. Manner H, Rabenstein T, Pech O, Braun K, May A, Pohl J, et al. Ablation of residual Barrett's epithelium after endoscopic resection: a randomized longterm follow-up study of argon plasma coagulation vs. surveillance (APE study). Endoscopy. 2013;46:6-12.

53. Zhang L, Dong L, Liu J, Lu X, Zhang J. Endoscopic ablation of Barrett's esophagus using the second generation argon plasma coagulation: a prospective randomized controlled trail. J. Nanjing Med Univ. 2009;23:183-8.

54. Dunn JM, Mackenzie GD, Banks MR, Mosse CA, Haidry R, Green S, et al. A randomised controlled trial of ALA vs. Photofrin photodynamic therapy for highgrade dysplasia arising in Barrett's oesophagus. Lasers Med Sci. 2013;28: 707-15.

55. Kohoutova D, Haidry R, Banks M, Butt MA, Dunn J, Thorpe S, Lovat L. Longterm outcomes of the randomized controlled trial comparing 5-aminolaevulinic acid and Photofrin photodynamic therapy for Barrett's oesophagus related neoplasia. Scand. J. Gastroenterol. 2018;53:527-32.

56. Winzer BM, Paratz JD, Whitehead JP, Whiteman DC, Reeves MM. The Feasibility of an Exercise Intervention in Males at Risk of Oesophageal Adenocarcinoma: A Randomized Controlled Trial. Plos One. 2015;10:e0117922.

57. Kharba M, Cheng P, Chan CH. Ultra-Short Segment Barrett's Oesophagus: is It Relevant? - Gastroenterology. 2019;S289

58. Bennett C, Moayyedi P, Corley DA, DeCaestecker J. BOB CAT: A Large-Scale Review and Delphi Consensus for Management of Barrett's Esophagus With No Dysplasia, Indefinite for, or Low-Grade Dysplasia. - PubMed - NCBI

59. van Munster SN, Pouw RE, Bergman JJGHM. Randomized studies for Barrett's ablation: just because we can doesn't mean we should. Gastrointest. Endosc. 2019;89:690-2.

60. Herrero LA, Pouw RE, Van Vilsteren FG, Sondermeijer C, Kate FJT, Fockens $P$. What Are the Outcomes of Endoscopic Radiofrequency Ablation for Very Long Segments of Barrett Esophagus Containing Neoplasia? Gastrointestinal Endoscopy. 2009. DOI: https://doi.org/10.1016/j.gie.2009.03.107. 